九州大学学術情報リポジトリ

Kyushu University Institutional Repository

\title{
Thoughts on Disasters
}

We inme ister, H. Wolfgang

Faculty of Agriculture, Kyushu Unviersity

Omura, Hiroshi

Faculty of Agriculture, Kyushu Unviersity

https://doi.org/10.5109/4691

出版情報：九州大学大学院農学研究院紀要. 50 (2)，pp.829-836，2005-10-01. Faculty of Agriculture, Kyushu University

バージョン:

権利関係 : 


\title{
Thoughts on Disasters
}

\section{H. Wolfgang WEINMEISTER and Hiroshi OMURA}

\author{
Laboratory of Erosion Control, Divison of Forest Environment and Management Science, \\ Department of Forest and Forest Products Science, Faculty of Agriculture, \\ Kyushu University, Fukuoka 812-8581 Japan \\ (Received June 30, 2005 and accepted July 26, 2005)
}

\begin{abstract}
We should not only take the scientific side into consideration in dealing with catastrophes but also the emotional one, the parapsychological one, the sociological one and the religious one. By mapping the endangered zones, by alarming before the event and by protective measures only, the problems will not be solved. If a disaster exceeds the previous and common order of magnitude and the protective measures don't suffice any longer, extensive knowledge about the kind of the hazard and the possibilities of immediate mastering is necessary to have a chances of survival. However, extensive knowledge is also necessary in case of a catastrophe to be able to help affected persons or survivors. It is a duty never to stop learning and improving all possibilities of disaster mitigation.
\end{abstract}

\section{INTRODUCTION}

The year 2004 will stay with us as a year of many and partly serious disasters. We struggle with the incomprehensibility of these catastrophes and feel sorry for the persons affected or killed. It particularly has met heavily Eastern Asia and South-Eastern Asia. Many typhoons swept over Japan and China and earthquakes caused numerous victims and great damages at Niigata and other parts of the world too. But just the great tsunami devastation in Indonesia, Sri Lanka, Thailand, India etc. called to memory of the remaining world its vulnerability by natural disasters. In this paper shall be thought about disasters in another form as now it is usual. The meaning of disasters in the history and for the development of mankind shall stand in the foreground.

\section{BASIC THOUGHTS}

Within the last few years the question was on our mind again and again: "What is truth?". Are we able to be correctly aware of the conditions around us? Our daily and practical attitude assumes that all what we see and hear or are aware is correct truth and it can be different from another truth. At court processes with different testimonies this gets very obvious. We would like to take a very pragmatic point of view here and therefore we take an evolutionary entrance for it. It also turns out, however, that we must distinguish what happens in our ideas (theories) and what in the outside world (IRRGANG 1993, LORENZ 1973, POPPER 1998, CHANGEUX 2004, AHL \& ALLEN 1996). A very plausible and pragmatic concept is: "Every improvement of our ideas, our theories about the processes in our surroundings or in ourselves, will cause more successful results of our actions". A good example of this approach is the development of astronomy. 
Ptolomaeus has improved a very old concept and already achieves very good results with the idea that all mobile bodies revolve around the earth. Copernicus has caused another essential improvement with the idea of the sun as a central star. Keppler's laws represent a next step of improvement. And the improvements in the theory about the solar system of today made it possible, to build a space shuttle, which accomplishes such remote goals as the Saturn moon Titan and send pictures from there to the earth.

Therefore it seems to be clear that the success (the result of an action) is in a direct connection with the quality of a theory (or the idea about an object or a function in the interaction of processes). Every improvement in our ideas, our theories, every increase of the plausibility of them, therefore leads to a greater success or lower failure of our actions in the end.

We support the idea that the theory of evolution namely, that the fitter organism, the better idea will be enforced, and the theory of self organizing (synergetic, HAKEN, 1990) namely, that in a complex system the evolution of this system is organized by itself, is very plausibly (JAYNES, 2003). These ideas (these theories) get by without every metaphysical approach and explain extremely plausibly many areas of the reality.

\section{RELIGION AND ANTHROPOLOGY}

To see, however, more clearly the significance of disasters for the human development, it is necessary to include the realm of the religion. The term religion is used here in the following meaning:

We don't understand a specific declared belief but that fundamental attitude of men which deals with the "last questions" (frames of the orientation and devotion in the meaning of E. FROMM 1980), the question about the death, the question about God, the rules of social life, the rites and the like. We assume that the origin of the religion goes back to the time of the anthropogenesis. The sudden recognition of men, that they can think about themselves, and the becoming aware that they must die, that there existence is limited and that there is the death, will have affected them heavily. With the appearance of the self-confidence the death also arises in the center of the life. Dealing with the death therefore gains big importance. The fear of dying and the thinking about what will happen after the death arise. If one may have faith in anthropology, the higher self-confidence has appeared about 195,000 years (McDOUGALL et al., 2005) ago when the Cro-Magnon man (MITHEN 2003, WILSON et al., 1999, LEAKEY, R.E., LEWIN 1996) developed. 190,000 years passed in a dark past history in which the schamanic methods of primitive religions (ELIADE 1975) evolved. During this time single particularly talented or thoughtful, with visions gifted men were thinking about their existence and discovered that the subconscious is influenceable. From this the different ecstasy or meditation techniques developed, which we find again in later more highly evolved religions. These special people surely also have discovered that they reached a certain special position due to their special knowledge. From this the class of the priest and priestesses is developed which later also practiced power and influence into and on the group of men.

To overcome the spiritual emptiness, which arises from the confrontation with the death, the idea of a life after the death seems to evolve. Further the belief in a divinity (Gods, God, Heavens) lying outside the existence of one's own or a supernatural power 
also results, a principle of hope as an antithesis to the apparent "insanity" of the life in connection with the death. It seems therefore plausible to us that some shamans or priests have used this principle of hope in their clan to secure surviving for their group and prevent from insanity and suicide. The idea is born that religion offers better chances for survival of the group (live after the death, rebirth, a transcendental nature=divinity, gods; an aim outside of oneself and outside of the clan).

In the time of the Neolithic revolution (CHILDE / MITHEN 2003) (approximately $10,000 \mathrm{BP}$ ) with the invention of the agriculture and the livestock breeding the complete situation of mankind changed radically. Higher religions among others just arose well only in Sumer and Egypt after our knowledge about 5,500 years ago. The importance of the death in the Egyptian religion and the faith in a continued existence after the death led in the effortful cult for the died people. In the context with this paper, the importance of the cult for the died people should also stimulate our thoughts.

The spreading of the modern man was carried out via Egypt, Palestine and the "fertile crescent" starting out from Africa to the other continents. A connection of all religions therefore seems justified; a further separated development in secluded enclaves looks very plausible. There is a common treasure of old traditions. These are the different ideas of a life after the death, a metaphysical relation to a divinity (heavens, God, gods, demons, spirits, ...) and rites in connection with the most important events of the community (birth, connection of the sexes, death, cultivation and harvest, unusual events with a strong impact on the population).

The disasters also occur in the history at this point. The influence of the disasters works with the fear. However, the fear increases at a disaster event to a collective fear, to the traumatic event, which is deeply impressed in the subconsciousness. One admittedly finds something like fear also at animals which react into situations of endangering of themselves by flight or defense.

What has happened before the written specification of the history is hardly known. It is interesting, though, that myths of the flood are found at almost all peoples over the whole globe (TOLLMANN \& TOLLMANN 1993, KOCH 2000). The biblical legend of Noa is the best known in the Judaic-Christian cultural area but also in the Greek mythology (Deukalionic Flood) in Indian mythology there are notes in the Babylonian area (Gilgamesh epic) in the Chinese area in America and Australia. Also other disaster events were converted in legends and interpreted in a changed manner. [e.g. Sodom and Gomorra (NEEV \& EMERY 1995), exodus from Egypt (eruption of the volcano Satorin in the Mediterranean near by Crete, tsunami, fire column (cloud) at night, column of smoke during the day; Moses, Exodus, 13, 21 (GÖRDIKE 2000)]. Some more geological evidence of cataclysmic events during the Mesolithic age is described by MITHEN (2003, pp. 150-157).

On the other hand we also can observe that there are in the different societies and religions certain rules ("golden rule") in the clan, the group, later the language stock, the nationality and at least in the mankind, however, which control the living together. One will be allowed to assume that according to the theory of evolution the emergence of the rules of the living together has developed also in an analogous way and has its roots very far in the past of mankind. It can be rather easily explained that the essential points of the "golden rule" are similar in all cultures. The declaration of the human rights is the 
conclusion of this development.

\section{CATASTROPHES AS A CONTRIBUTION TO THE EVOLUTION}

The paleontologic research shows several deep cuts with a strong diminution of the species numbers and reduction of population sizes within the evolution of life.

PRIMACK (1993) arranges the five most important episodes of extinction. At the border of Permian to Triassic Period the greatest extinction took place. It is appreciated almost generally that the dinosaur extinction happened due to an impact of an asteroid on the peninsula Yucatan in Mexico. There are different theories for the different events of extinction. Volcanic activity and climate change play an important role besides impact theories. It seems also plausible that disasters had a strong influence on the development of the human culture. Multiple notes can be found in MITHEN (2003) or ELVIN (2004). TOLLMANN (1993), HOYLE (1997) and KOCH (2000) also report about it. So the hypothesis is here put forward that the different migration of mankind has been connected to disasters since past (droughts, ice, earthquakes, tsunamis, floods, fires). Because of the numerous changes of climate during the Pleistocene period which are proved in many deep sea and ice drillings, the world-wide spreading of men becomes very understandable. But also the mastering of the disasters by customization and new technologies becomes obviously.

\section{DEALING WITH DISASTERS}

How disasters were handled in the historical time can be looked up for the European area by SONNABEND (1999). Reports on the importance of disasters in China can be found in ELVIN (2004). One runs through these reports: disasters were looked predominantly as a punishment of the divinity (Poseidon, God, Heaven) and atoned by sacrificial offerings and rites of reconciliation. An active precaution of disasters or mastering appears relatively late.

Although the scientific analysis of catastrophes already goes back on the Greek and Romans (Thales, Anaximander, Anaximenes, Aristotle, Plinius the elder, and others, SONNABEND 1999), acceptance of this position is gained, however, only after the great earthquake connected with a tsunami 1755 which have destroyed Lisbon (VOLTAIRE / NNZ 2005, GUTSCHER 2004). About this event it is reported that during this disaster the only part of the city was spared which was located more high. This part was the red-light district (prostitution). So doubts arose that this disaster was sent by God because of the depravity of people. In the opinion of the Roman Catholic priests, the hustle and bustle of the prostitute was regarded as special repulsive and godless. Only during the enlightenment epoch which forced back the influence of the Catholic Church in Europe it became possible to look for and to find natural causes of the disasters, and therefore it became possible to overcome the ancient ideas.

A science for the investigation of disasters could begin. A separate investigation of the different kinds of disasters started and a specific prevention of disasters or the elimination of their effects began in distinct cultures at several times and reached different levels. Furthest seems to be the development in Japan today if all catastrophe types are 
looked together. The international decade for the reduction of natural disasters (IDNDR) has world-wide strengthened the consciousness and brought many suggestions.

\section{CONCERN AND AFFLICTION}

Perhaps one should look at the degrees of affliction concerning one person, the family or the clan, the nation or the whole mankind. The single person, the family, the clan, is confronted with a catastrophe much more fatefully than nations or mankind as a whole. The death of a single person generally concerns the small group (the family or the clan). In a small group the reminding and a "life after death" take place. Only if bigger areas or many people are concerned, the concern climbs to a national or international level. Great sudden solidarity can be observed after the tsunami event of 12-26-2004. This completely is unlike the neo-liberal development in the economy in which there are only competition and no more solidarity. The question suddenly arises, is the humaneness called in memory again only by such catastrophes?

The knowledge about the natural causes of catastrophes, their not quite accidental occurrence, however unavoidable appearance, can help us, to overcome the believe that catastrophes are anger and punishment of the divinity against which we cannot do anything. The ancient thought to reconcile the divinity by rogation and sacrifices had the meaning for the individual and also for the community, that the asking group together can turn away the evil by praying and by a "bringing the thoughts on line" to develop an intellectual strength as it can be watched at many collective events. There are many very different examples for it. Starting with the dances in "primitive" societies, the prayer and meditation experience in Christian communities (monastery of Taizé in France, STEINDL-RAST 1984), concert experiences with classical music or also the mass suggestion of a rock concert. But what intellectual rectification (bringing the thoughts on line) can cause is observable at the spreading out of the early Christianity or also at splashing over of revolutions. Rites are probably connected with such spiritual orientations and therefore also have to be understood as adaptation to the situation and have great importance for the mastering of emergency and harm. Although rites cannot protect from a disaster, but they can help to mitigate the emotional consequences of the catastrophe.

\section{IDEAS FOR FUTURE DEALING WITH CATASTROPHES}

In our opinion the mastering of catastrophe must therefore be done from two sides: From the physical (technical) side, that is the understanding of the processes and effects, and from the spiritual side, the overcoming of the emotional and traumatic consequences of the involved people. A personal mastering of disasters gets possible by that. The belief to be able to help oneself if one knows how to do, means a considerably bigger chance to survive. We have heard a story of a 10-year-old girl ${ }^{1}$ who had learned in school that before the appearance of a tsunami the water-level of the sea sinks and therefore large parts of the shores lie dry. She has reacted to it and helped many people to get the flight and therefore saved the lives at the event of December 26th, 2005. We are convinced that

\footnotetext{
1 http://www.n-tv.de/5471483.html
} 
it is necessary to start he catastrophe-training already in primary school. Exercises also should be connected with that. Such exercises are already standard in Europe in case of a fire in a school; in other countries such exercises also can be found.

On a journey into the west of North America the first author had observed that it is natural and usual to point out the different hazards. A booklet on the right behavior in the case of an earthquake lied in every supermarket in Vancouver BC next to the cashier's desk. Leaflets lied at every camping site about the behavior in case of the appearance of bears, wolves and the like. It is international praxis today in every hotel that a flight plan is hung up visibly which it makes possible to escape quickly in the case of emergency. The first author didn't understand that a similar suggestion to establish a booklet on behaviors during danger of avalanches in every hotel room was rejected by avalanche managers at a meeting ${ }^{2}$ in Brussels in connection with the avalanche catastrophes of the winter 1998/99 because it could be harmful for the tourism. An Austrian tourist surviving in Thailand also has suggested in a television interview a similar demand with regard to tsunamis and other hazards connected to the beach for the hotels there. Relevant information on high standard about hazards should therefore be natural in future.

Measures for the reduction of the consequence of natural disasters should be adapted to the standard of the development of the civilization because their financing will cause great problems. However, if it is possible, to get an international fund, which can help to compensate the different standards of countries, would be a big step forwards. In Austria financially weak communities get a greater support from the state than financially strong ones for mitigation measures against avalanches and torrents. It seems evident that these measures shall be ecologically and socially compatible, economically appropriate and technologically mature. All that together means sustainable development. However, until now there is no clear psychological, sociological and religious handling of mastering of catastrophes. Therefore a lot of efforts are necessary.

Although disasters have natural causes, there exists more or less a component, made by men too. We think on the settlement and use of risky areas, on dealing with nature and landscape (extensive clearing like in the Mediterranean area of Europe, China and nowadays South America, interventions in natural processes with an amplified positive feedback like structural flood protection (river regulation) in Middle Europe by which a lot of flood retention volume was lost and therefore the flood peaks amplified, backwater behind a dam and triggering of landslides (Vajont)) or on the destruction of nature and landscape by warfare.

A first approach to a social mastering of disasters is the hazard mapping. Its necessity is undisputed. Austria has started hazard mapping already 30 years ago, and nowadays it is spreading out round the world.

But a religious mastering of the disasters, which includes the intellectual development of the last centuries, is still far away. On the contrary, both the creationist and fundamentalists have got more and more influence all over the world. This could be dangerous in the sense of neglecting rational thinking in favour of preconceived ideas. How shall be solved the conflict between scientific knowledge about disasters and the faith that catastrophes are divine punishment?

28.04 .1999 
This conflict seems to be more significant in the monotheistic religions. In connection with great catastrophes one can observe that animals have presentiments. Some details were found at the internet ${ }^{3}$ after the tsunami catastrophe. There also are similar reports of presentiments of humans like prophecies and similar parapsychological phenomena in connection with catastrophes. We hold the opinion that such phenomena exist, however, we are not able to explain with our currently scientific methods.

The statistics of the Red Cross (INTERNATIONAL RED CROSS and RED CRESCENT 1993) of the last decades show that the greatest misery arises in connection with warfare. For us the most important thing would be to enhance world wide efforts (intellectual and financial) to avoid wars. A lot of lives and natural resources could be saved, and this surely is the main goal of disaster mitigation. But what does the human society do against wars?

\section{REFERENCES}

AHL, V., ALLEN, T. F. H. 1996 Hierachy Theory - A Vision, Vocabulary, and Epistemology, Columbia University Press, New York, S. 206.

CHANGEUX, J-P. 2004 The Physiology of Truth - Neuroscience and Human Knowledge, (L'Homme de vérité; Editions Odile Jacob, 2002), Belknap Press of Havard Uni Pr, Cambridge, Ma London, S. 324

CHILDE, V. G. cit. By MITHEN 2003 compare rem. 6

ELIADE, M. 1975 Schamanismus und archaiische Ekstasetechnik, STW 126, Suhrkamp, Frankfurt, S. 472

ELVIN, M. 2004 The Retreat of the Elephants - an Environmental History of China, Yale University Press, New Haven London, S. 564

FROMM, E. 1980 Psychoanalyse und Religion [Psychoanalysis and Religion (1950a)], Bd. 6, Religion, Deutsche Verlagsanstalt G, Stuttgart, S. 227-299

GÖRDIKE, H. 2000 Mündliche Mitteilung

GUTSCHER, M. A. 2004 What Caused the Great Lisbon Earthquake? Science Vol 305, No. 5688, S.: $1247-1248$

HAKEN, H 1990 Synergetik: eine Einführung. 3., erw. Aufl. Berlin Springer

HOYLE, F. 1997 Kosmische Katastrophen und der Ursprung der Religion, Insel, Frankfurt Leipzig, S. 135

INTERNATIONAL RED CROSS and RED CRESCENT 1993 World Disaster Report 1993, M. Nijhoff Publisher, Dordrecht, Norwell.

IRRGANG, B. 1993 Lehrbuch der Evolutionären Erkenntnistheorie, UTB, 1765, Reinhardt, München, Basel, S. 303.

JAYNES, E. T. 2003 Probability Theory - The Logic of Science, Cambridge University Pres, Cambridge New York, S. 727

KOCH, H. P. 2000 Sintflut - Die Bibel berichtet von der Urkatastrophe der Menschheit, Kremayr \& Scheriau, Wien München Zürich, S. 336

LEAKEY, R. E., LEWIN, R. 1996 Wie der Mensch zum Menschen wurde, (Origins, London 1977), Hoffmann und Campe, Hamburg, S. 302

LORENZ, K. 1973 Die Rückseite des Spiegels, Versuch einer Naturgeschichte des menschlichen Erkennens, Piper, München Zürich, S. 338

McDOUGALL, I., BROWN, F. H., FLEAGLE, J. G. 2005 Stratigraphic placement and age of modern humans from Kibish, Ethiopia, Nature 433: 733-736

\footnotetext{
${ }^{3}$ http://www.learn-line.nrw.de/angebote/agenda21/lexikon/tsunami.htm, http://www.3sat.de/3sat.php? http://www.3sat.de/nano/astuecke/74638/
} 
MITHEN, St. 2003 After the Ice Age - A Global History 20,000 - 5000 BC, Phoenix, London, S. 622

NEEV, D:, EMERY, K. O. 1995 The Destruction of Sodom, Gomorrah, and Jericho, Geological, Climatological, and Archeological Background, Oxford University Press, New York Oxford, S. 175

POPPER, K. R. 1998 Objektive Erkenntnis - Ein evolutionärer Entwurf, Hoffmann \& Campe, Hamburg, S. 413

PRIMACK, R. B. 1993 Essentials of Conservation Biology, Sinauer Ass. Inc., Sunderland, S. 564

SONNABEND, H. 1999 Naturkatastrophen in der Antike-Wahmehmung Deutung Management, J. B. Metzler, Stuttgart Weimar, S. 269

STEINDL-RAST 1984 Gratefulness, The Heart of Prayer, Ramsey New Jersey, Paulist Press: pp. 192 TOLLMANN, A, TOLLMANN, E 1993 Und die Sintflut gab es doch-vom Mythos zur historischen Wahrheit, Vlg. Droemer Knaur, München, S. $180 \mathrm{ff}$

VOLTAIRE, 2005 Poème sur le Désastre de Lisbonne" nach NZZ (19.01.2005, S. 9).

WILSON, R. C. L., DRURY, S. A., CHAPMAN, J. L. 1999 The Great Ice Age, Climate Change and Life, Routledge, London, New York, S. 267 